\title{
Ghrelin Is a Regulator of Glucagon- Like Peptide 1 Secretion and Transcription in Mice
}

\author{
Andreas Lindqvist, Liliya Shcherbina, Ann-Helen Thorén Fischer and Nils Wierup* \\ Department of Clinical Sciences, Lund University Diabetes Centre, Malmö, Sweden
}

The gut hormones ghrelin, glucagon-like peptide 1 (GLP-1), and glucose-dependent insulinotropic peptide (GIP) have been intensively studied for their role in metabolism. It is, however, not well known whether the hormones interplay and regulate the secretion of each other. In this study, we studied the effect of ghrelin on GLP-1, GIP, and insulin secretion during an oral glucose tolerance test (OGTT) in mice. Intravenous administration of ghrelin caused increased GLP-1 secretion during the OGTT. On the other hand, ghrelin had no effect on circulating levels of glucose, insulin, and GIP. Furthermore, ghrelin treatment reduced proglucagon mRNA expression in GLUTag cells. The effect of ghrelin on GLP-1 secretion and proglucagon transcription was reinforced by the presence of

OPEN ACCESS

Edited by: Hubert Vaudry,

University of Rouen, France

Reviewed by:

Odile Viltart,

Lille University of Science and

Technology, France

Laurent Gautron

University of Texas Southwestern Medical Center, United States

Masayasu Kojima,

Kurume University, Japan

*Correspondence:

Nils Wierup

nils.wierup@med.lu.se

Specialty section: This article was submitted to Neuroendocrine Science, a section of the journal

Frontiers in Endocrinology

Received: 20 January 2017 Accepted: 01 June 2017

Published: 19 June 2017

Citation:

Lindqvist A, Shcherbina L, Fischer A-HT and Wierup N (2017) Ghrelin Is a Regulator of Glucagon-

Like Peptide 1 Secretion and

Transcription in Mice.

Front. Endocrinol. 8:135. doi: 10.3389/fendo.2017.00135
GHS-R1a in human and mouse ileal L-cells, as well as in GLUTag cells. In summary, ghrelin is a regulator of GLP-1 secretion and transcription, and interfering with GHS-R1a signaling may be a way forward to enhance endogenous GLP-1 secretion in subjects with type 2 diabetes.

Keywords: ghrelin, glucagon-like peptide 1, GLUTag cells, oral glucose tolerance test, GHS-R1a

\section{INTRODUCTION}

The gastrointestinal tract harbors an array of hormones and regulatory peptides, involved in control of processes ranging from food intake to glucose homeostasis (1). Although the biological significance of the major gut hormones is well established, the interplay between different gut hormones is not well known and needs further investigation. Glucagon-like peptide 1 (GLP-1) is a product of the proglucagon gene produced by L-cells in the distal intestine, mainly in the ileum and colon. GLP-1 is known to increase insulin secretion (2) and beta cell proliferation (3) and to inhibit intestinal motility (4), gastric emptying (5), and food intake (6). GLP-1 chemistry is an area targeted for the treatment of type 2 diabetes (T2D) and GLP-1 analogs and inhibitors of the GLP-1-degrading enzyme DPP-IV are successfully used in clinical practice (7). Glucose-dependent insulinotropic peptide (GIP) is, on the other hand, produced in K-cells mainly located to the proximal parts of the small intestine. GIP has many effects that are similar to those of GLP-1 including stimulating insulin secretion $(8,9)$ and promoting beta cell proliferation $(10,11)$. Increased understanding of the mechanisms regulating incretin secretion is important to understand normal physiology and may pave the way for new targets for the treatment of T2D. Ghrelin is a 28 -amino acid peptide hormone produced by P/D1 cells in the oxyntic mucosa of the stomach (12), in the upper small intestine (13), and in a distinct cell type in the pancreatic islets (14). Normoglycemic lean humans have elevated ghrelin levels in response to fasting and the levels decrease upon meal ingestion (15). Central and peripheral administration of ghrelin in rodents and humans has been shown to increase food intake (16-18) and to inhibit insulin secretion (19). Furthermore, ghrelin has been shown to inhibit insulin secretion in isolated mouse islets $(20,21)$ and in clonal beta cells $(22,23)$. Obese individuals have lower fasting levels of ghrelin (24) and deranged suppression of ghrelin levels upon meal ingestion (25). Furthermore, lean T2D 
patients have higher levels of fasting ghrelin, whereas obese T2D subjects have lower levels of fasting ghrelin, than do normoglycemic lean control subjects (26). The GLP-1 analog, exendin-4 reduces ghrelin levels in fasting rats (27) and GLP-2, another product of the proglucagon gene, suppresses ghrelin secretion in humans (28). Furthermore, ghrelin was reported to attenuate the effects of GLP-1 on food intake (29). Two studies have shown that ghrelin regulates GLP-1 secretion and production, but the available data are somewhat contradictory $(30,31)$. Here, we aimed to assess the effect of intravenously administered ghrelin on GLP-1 and GIP secretion in response to an oral glucose tolerance test (OGTT). Our results suggest that intravenous administration of ghrelin increases GLP-1 secretion during an OGTT and that ghrelin affects proglucagon transcription in vitro in GLUTag cells.

\section{MATERIALS AND METHODS}

\section{Mice}

Female C57BL/6NTac mice (approximately 25 g; 4-5 weeks of age) were housed in climate-controlled rooms $\left(23 \pm 1^{\circ} \mathrm{C}\right)$ with a 12:12 h light-dark cycle. Food and water were provided ad libitum unless otherwise stated. All the experiments in this study were approved by and performed in accordance with the Animal Ethics Committee, Lund and Malmö, Sweden (Ethical permit number M458-12).

\section{Oral Glucose Tolerance Test}

The mice were fasted for $4 \mathrm{~h}$ before the oral glucose tolerance test (OGTT). OGTTs were performed at 1300. The mice were anesthetized using an intraperitoneal injection of Hypnorm/Dormicum (10 $\mu \mathrm{l} / \mathrm{g}$ BW; fentanyl $0.315 \mathrm{mg} / \mathrm{ml}$, fluanison $10 \mathrm{mg} / \mathrm{ml}$, and midazolam $5 \mathrm{mg} / \mathrm{ml}$ ). Basal blood samples $(40 \mu \mathrm{l})$ were collected through retro-orbital puncture and ghrelin [50 nmol/kg (21); Phoenix Pharmaceuticals, Burlingame, CA, USA] or saline was injected intravenously in a tail vein 5 min prior to glucose administration $(32,33)(n=18$ and $n=15$, respectively). At time 0 , glucose $[3 \mathrm{mg} / \mathrm{g}$ body weight $(32,33)]$ was given orally through gavage. Blood samples (40 $\mu \mathrm{l} /$ time point) were collected at $10,20,30,60$, and $90 \mathrm{~min}$ through retro-orbital puncture. After glucose tolerance tests, the mice were kept overnight under a heating lamp for recovery.

\section{Blood Collection}

Blood was collected in chilled tubes supplemented with $500 \mathrm{KIU} / \mathrm{ml}$ Aprotinin (Trasylol ${ }^{\circledR}$; Leverkusen, Germany) and $100 \mu \mathrm{mol} / \mathrm{ml}$ of the DPP-IV inhibitor Diprotin A (Sigma Aldrich, St. Louis, MO, USA). Plasma $\left(1,500 \times g, 3 \mathrm{~min}, 4^{\circ} \mathrm{C}\right)$ was stored at $-80^{\circ} \mathrm{C}$ until analysis.

\section{Hormone Analyses}

Active GLP-1, total GIP, and total ghrelin were analyzed using ELISAs from Millipore (Darmstadt, Germany). Insulin was analyzed using an ELISA from Mercodia (Uppsala, Sweden), and glucose was analyzed using a commercially available kit (Infinity Glucose Oxidase) from Thermo Fisher Scientific (Lexington, MA, USA). Assays were performed according to the instructions provided by the manufacturers.

\section{Cell Culture}

The GLUTag cell line (provided by Dr. Daniel J. Drucker, Mount Sinai Hospital, Toronto, ON, Canada) was originally isolated from a glucagon-producing enteroendocrine tumor in mice. GLUTag cells were routinely cultured in Dulbecco's modified Eagle's medium, $1 \mathrm{~g} / \mathrm{l}$ glucose, supplemented with 10\% FBS, and $2 \mathrm{mM}$ glutamine. For ghrelin treatment, cells were seeded in 24 -well plates at a density of 250,000 cells/well and cultured for $24 \mathrm{~h}$. Thereafter, medium was replaced by new medium with or without ghrelin at concentrations of $10 \mathrm{nM}, 100 \mathrm{nM}$, and $1 \mu \mathrm{M}$ and cells were incubated for $24 \mathrm{~h}$.

\section{Quantitative Real-time PCR}

RNA was extracted from GLUTag cells using a commercially available kit (Nucleo Spin RNA II, Macherey Nagel, Bethlehem, PA, USA). cDNA was generated using a RevertAid First Strand cDNA Synthesis kit (Thermo Fisher Scientific, Waltham, MA, USA). Real-time PCR was run using TaqMan ${ }^{\circledR}$ assays [GLP-1, Mm1269055_m1; peptidylpropyl isomerase A (PPIA) Mm02342429_g1]. 25 ng of cDNA was run under the following conditions: 1 cycle of $50^{\circ} \mathrm{C}$ for $2 \mathrm{~min}$ and $95^{\circ} \mathrm{C}$ for $10 \mathrm{~min}$ followed by 40 cycles of $95^{\circ} \mathrm{C}$ for $15 \mathrm{~s}$ and $60^{\circ} \mathrm{C}$ for $1 \mathrm{~min}$. The mRNA expression was calculated using the $2^{-\Delta \Delta(\mathrm{Ct})}$ formula and expressed as arbitrary units in relation to PPIA expression that was used as reference gene.

\section{Tissue Collection}

Mouse ileum was collected from female C57BL/6NTac mice (approximately $25 \mathrm{~g}$ body weight), and specimens from human terminal ileum were taken during colonoscopy as previously detailed (13). The studies were approved by the Human Ethics Committee in Lund.

\section{Immunohistochemsitry}

Specimens of human and mouse ileum were fixed in $4 \%$ paraformaldehyde and embedded in paraffin. Sections $(6 \mu \mathrm{m})$ were cut on a microtome, and slides were incubated with previously characterized primary antibodies for ghrelin receptor (GHSR1a) (rabbit antibody; code: H-001-62, dilution: 1:400, Phoenix Pharmaceuticals, Burlingame, CA, USA), proglucagon (guinea pig antibody; code: M7807, dilution: 1:5,000, EuroDiagnostika, Malmö, Sweden), and GIP (goat antibody; code: sc-23554; dilution 1:500, Santa Cruz Biotechnology, Houston, TX, USA) overnight at $4^{\circ} \mathrm{C}$. Thereafter, slides were incubated with secondary antibodies [donkey anti-rabbit Cy2 (1:400) for GHS-R1a, donkey anti-guinea pig Texas Red (1:400) for GLP-1, and donkey anti-goat Texas Red (1:400) for GIP] for $1 \mathrm{~h}$ at room temperature. GLUTag cells were cultured on cover slips and incubated with GHS-R1a antibody (code: 00020; dilution: 1:400) overnight at $4^{\circ} \mathrm{C}$. Secondary antibody (donkey anti-rabbit Cy2; 1:400) was applied and incubated for $1 \mathrm{~h}$ at room temperature. Nuclei was stained with $1 \mu \mathrm{M}$ DAPI (Thermo Fisher Scientific, Waltham, MA, USA).

\section{Statistics}

Data are presented as mean \pm SEM. Statistical significance was calculated using one-way or two-way ANOVA where appropriate using the software GraphPad Prism 6 (GraphPad Software Inc., 
La Jolla, CA, USA). Differences were considered significance if $p<0.05$.

\section{RESULTS}

\section{Effect of Intravenous Ghrelin on GLP-1, GIP, and Insulin Release during an OGTT}

Ghrelin had no effect on basal GLP-1 levels, but glucosestimulated GLP-1 secretion was found to be transiently increased in mice that had received intravenous administration of ghrelin (Figure 1A). Thus, AUC for GLP-1 was increased approximately 1.5 -fold ( $p<0.05$; Figure 1B). On the other hand, basal and glucose-stimulated plasma levels of insulin, GIP and glucose (Figures 1C-E) were unaffected by ghrelin administration. Elevated circulating ghrelin levels in ghrelin-treated mice were confirmed (Figure 1F).

\section{Effects of Ghrelin on Proglucagon mRNA in GLUTag Cells}

Having established that ghrelin affects GLP-1 plasma levels, we next assessed whether ghrelin impacts on proglucagon transcription. To this end, GLP-1-expressing GLUTag cells were used as a model. Ghrelin was added to the media at different concentrations $\left(10^{-6}, 10^{-7}\right.$, and $\left.10^{-8} \mathrm{M}\right)$ and cells were cultured for $24 \mathrm{~h}$.
A

Ghrelin

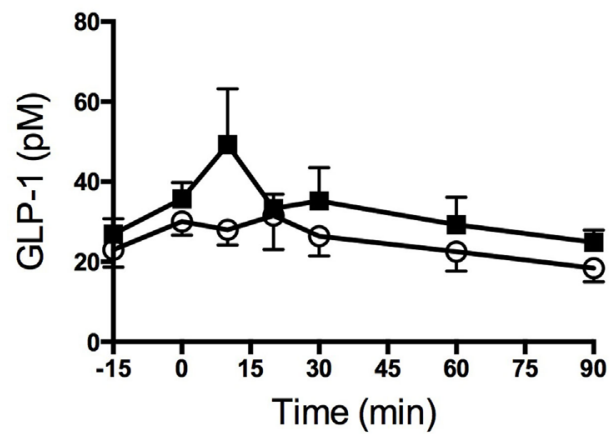

C

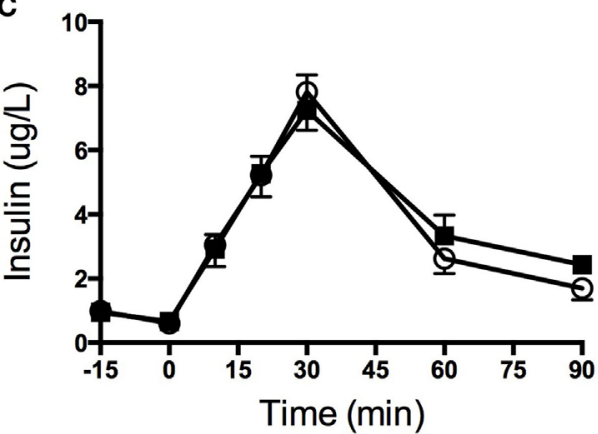

E

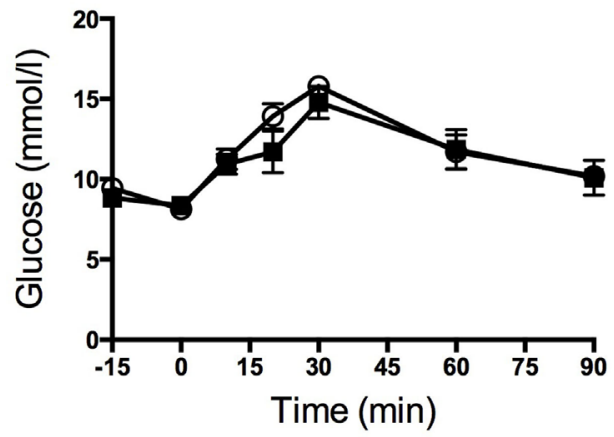

B Saline

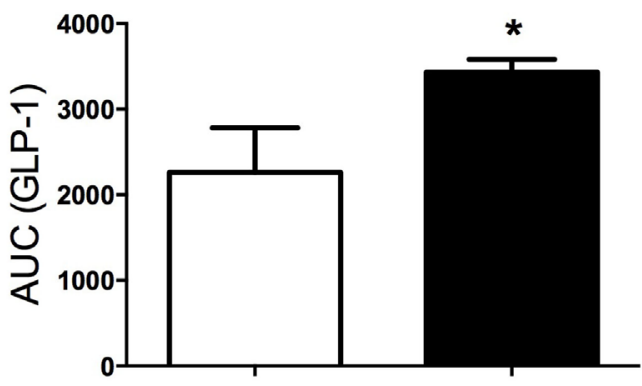

D

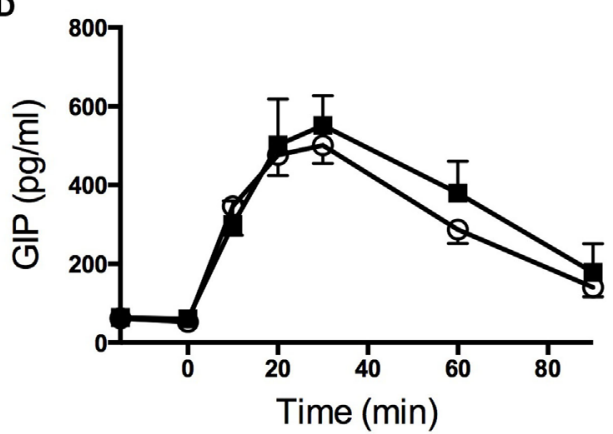

$\mathbf{F}$

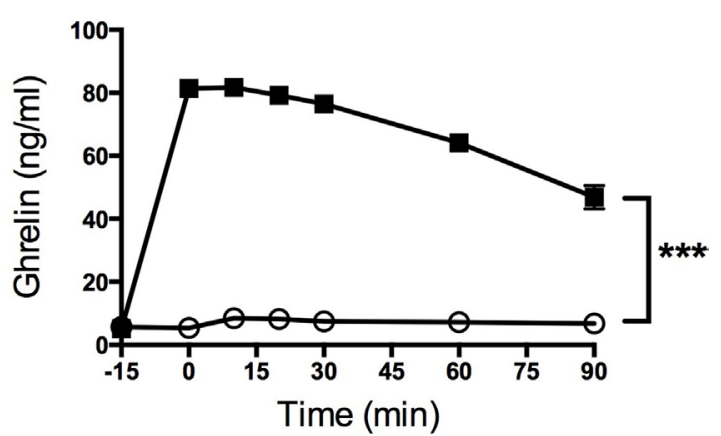

FIGURE 1 | Glucagon-like peptide 1 (GLP-1) secretion was increased in mice receiving ghrelin intravenously $(50 \mathrm{nmol} / \mathrm{kg})$ (A). AUC calculations revealed a statistically significant increase in GLP-1 after ghrelin injection (B). Insulin (C), glucose-dependent insulinotropic peptide (GIP) (D), and glucose (E) were unaffected by ghrelin treatment. Hyperghrelinemia in the mice was confirmed by significantly elevated levels of circulating ghrelin in the group of mice having received intravenous administration of ghrelin (F). ${ }^{*} p<0.05 ;{ }^{* \star *} p<0.001$. All statistical analyses were performed using two-way ANOVA except for (B) where Student's $t$-test was applied. 


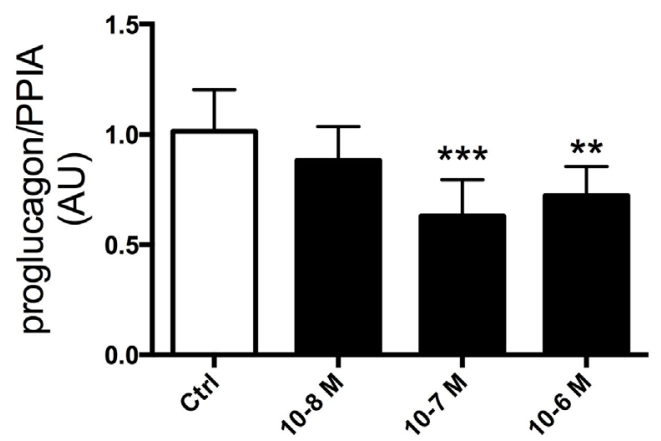

FIGURE 2 | GLUTag cells were incubated with $10^{-6}$, $10^{-7}$, or $10^{-8} \mathrm{M}$ ghrelin for $24 \mathrm{~h}$. Cells treated with $10^{-6}$ and $10^{-7} \mathrm{M}$ ghrelin displayed reduced proglucagon mRNA expression compared to control cells. ${ }^{* \star} p<0.01$; ${ }^{\star \star *} p<0.001$. Statistical analysis was performed using one-way ANOVA. Experiments were repeated in eight passages of cells $(n=8)$.

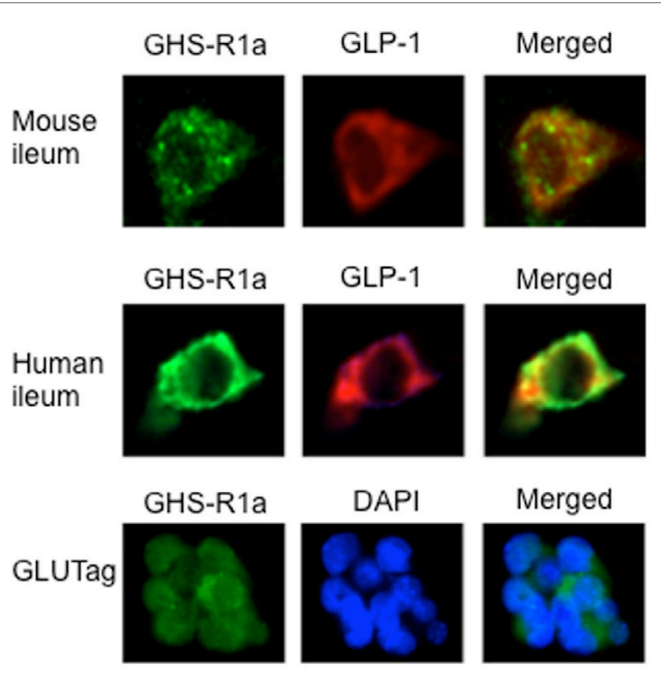

FIGURE 3 | The presence of the ghrelin receptor, GHS-R1a, was confirmed in mouse and human ileum using immunohistochemistry. Double staining with glucagon-like peptide 1 (GLP-1) revealed that GHS-R1a is colocalized with GLP-1 in mouse and human ileum (upper panel). GHS-R1a immunoreactivity was also evident in GLUTag cells (lower panel).

This revealed that addition of ghrelin $\left(10^{-6}\right.$ or $\left.10^{-7} \mathrm{M}\right)$ resulted in reduced proglucagon mRNA expression compared with vehicle-treated control cells $(p<0.01$ and $p<0.005$, respectively; Figure 2).

\section{GHS-R1a Expression in Mouse and Human Ileum}

Our data on the effect of ghrelin on GLP-1 secretion imply that L-cells express ghrelin receptors (GHS-R1a). To test this, we double stained mouse and human ileal sections for GHS-R1a and proglucagon. This revealed that GLP-1-producing L-cells harbored GHS-R1a expression in both species (Figure 3). On the other hand, GIP-producing K-cells were devoid of
GHS-R1a (data not shown). Furthermore, stainings for GHSRla confirmed GHS-R1a expression also in GLUTag cells (Figure 3).

\section{DISCUSSION}

The gut hormones ghrelin and GLP-1 have been extensively studied the last decade. However, it is still not fully understood how they interplay. Here, we show that intravenously administered ghrelin stimulates secretion of GLP-1 in vivo in mice, as well as that ghrelin affects GLP-1 transcription in an in vitro model of L-cells. On the other hand, ghrelin had no effect on plasma levels of GIP, insulin, or glucose.

Our data on the stimulatory effect of ghrelin on GLP-1 gain support from a recent study by Gagnon et al. who reported stimulatory effects of ghrelin on GLP-1 secretion in vivo in mice and in vitro in GLUTag and NCI-H716 cell lines via MAPK-dependent pathways (30). Furthermore, the authors demonstrated a role for endogenous ghrelin as a regulator of GLP-1 since treatment with a ghrelin receptor antagonist reduced circulating GLP-1 levels. In contrast to our present data, Gagnon et al. found ghrelin administration to reduce glucose levels paralleled by a minute increase in insulin secretion. Interestingly, these effects were absent in mice lacking the GLP-1 receptor and in wild-type mice cotreated with a GLP-1 receptor antagonist (30). The divergent data with respect to insulin and glucose levels may be related to differences in study design between the study by Gagnon et al. and the present study. First, different doses of ghrelin were used; Gagnon et al. used a fourfold higher dose of ghrelin (200 vs $50 \mathrm{nmol} / \mathrm{kg}$ ). Second, the timing of ghrelin injection differed. Gagnon et al. injected ghrelin at $-15 \mathrm{~min}$, whereas in the present study, ghrelin was injected at $-5 \mathrm{~min}$. Third, the administration route differed. Whereas ghrelin was administered intravenously in the present study, Gagnon et al. administered ghrelin intraperitoneally. Also, in the present study, active GLP-1 was measured, while Gagnon et al. measured total GLP-1. Although it is difficult to compare the effect of acute administration of ghrelin with that of life long absence of the ghrelin receptor, our data and the data by Gagnon et al. are not in accordance with the data, presented by Xu et al., on increased circulating levels of GLP-1 in GHS-R1A null mice. However, it needs to be mentioned that $\mathrm{Xu}$ et al. only reported basal levels of GLP-1 and did not assess GLP-1 levels during a glucose tolerance test (31).

The two previous reports also assessed GLP-1 secretion from cell lines, but there is no consensus on the direction of the effect. Thus, Xu et al. (31) showed that ghrelin suppresses active GLP-1 secretion in STC-1 cells, whereas Gagnon et al. found ghrelin to increase GLP-1 secretion in GLUTag cells and NCI-H716 cells (30).

Our present in vivo data are in agreement with a study in humans by Tong et al. (34) who elegantly showed that during a meal tolerance test, infusion of a high dose of ghrelin increased the postprandial response of GLP-1, without affecting GIP, peptide YY, or glucagon. On the other hand, ghrelin had no effect on GLP-1 levels during an intravenous glucose tolerance test (IvGTT) (34). Furthermore, insulin secretion rate adjusted for glucose was reduced by ghrelin infusion. 
In this study, ghrelin administration had no effect on insulin and glucose levels during the OGTT. This is in contrast to previous reports showing that ghrelin inhibits insulin secretion in different models and settings, including IvGTT in mice (21), in vitro studies in isolated islets and clonal cells $(21-23,35)$, as well as in vivo in humans $(34,36)$. To the best of our knowledge, the effect of intravenously administered ghrelin on insulin secretion during an OGTT in mice has not been reported previously. Fusco et al. administered ghrelin intravenously to obese patients with or without polycystic ovary syndrome and found ghrelin to suppress insulin secretion during an OGTT (37). However, incretin levels were not measured (37). We suggest that a possible explanation for the lack of effect of ghrelin on insulin in this study may be a result of the stimulatory actions of GLP-1 masking the inhibitory effect of ghrelin on the beta cell.

Furthermore, intravenous ghrelin administration had no effect on circulating levels of GIP during the OGTT. This is in line with the data presented by Tong et al. in healthy human subjects (34). As the half-life of ghrelin is approximately $85 \mathrm{~min}$ (38), it seems unlikely that this would contribute to the observations presented here.

We also showed that ghrelin reduced proglucagon mRNA expression in GLUTag cells, an in vitro model of L-cells. This observation was unexpected in light of the stimulatory effects of ghrelin on GLP-1 secretion in vivo. There is no ready explanation for the divergent data, and it is not known whether ghrelin has the same effect in L-cells in vivo. However, our present data gain support from similar observations in STC-1 cells (31). It should be mentioned that the effect on circulating levels of GLP-1 in vivo was evident within minutes, whereas the effect of ghrelin on proglucagon mRNA in GLUTag cells was seen after $24 \mathrm{~h}$ of culture. Furthermore, the effect of ghrelin on proglucagon mRNA integrity is not known. Further studies are needed to understand the impact of ghrelin on GLP-1 transcription and production.

Nevertheless, our functional data gain support from our confirmatory finding of GHS-R1a expression in L-cells in human and murine ileum, as well as in GLUTag cells. Thus, providing anatomical prerequisites for a direct effect of ghrelin on L-cells. Gagnon et al. demonstrated GHS-R1a mRNA expression in GLUTag and NCI-H716 cells (30). In this study, we confirm the previous findings of $\mathrm{Xu}$ et al. who demonstrated the presence of GHS-R1a in L-cells in murine ileum (31). The lack of effect of ghrelin on GIP secretion shown here and reported by Tong et al. (34) is most likely explained by our present finding of lack of GHS-R1a in K-cells.

In summary, during an oral glucose challenge, intravenously administered ghrelin stimulates circulating levels of GLP-1, without affecting levels of GIP, insulin, or glucose. Furthermore, ghrelin affects GLP-1 transcription and we confirm previous observations that murine L-cells express GHS-R1a and also show that human ileal L-cells express GHS-R1a.

\section{ETHICS STATEMENT}

The experiments were approved by the Animal Ethics Committee, Lund and Malmö, Sweden.

\section{AUTHOR CONTRIBUTIONS}

AL performed analyses and co-wrote the manuscript. LS performed analyses. A-HF performed surgeries. NW conceptualized the study and wrote the manuscript.

\section{FUNDING}

This work was supported by grants from the Swedish Research Council (Dnr. 2008-4216 and 521-2012-2119). This project is financially supported by the Swedish Foundation for Strategic Research. In addition, the project was also funded by the Albert Påhlsson Foundation, the Swedish Diabetes Foundation, ALF, the Novo Nordisk Foundation, the Royal Physiographical Society in Lund, and the Medical Faculty at Lund University.

\section{REFERENCES}

1. Tan T, Bloom S. Gut hormones as therapeutic agents in treatment of diabetes and obesity. Curr Opin Pharmacol (2013) 13:996-1001. doi:10.1016/j. coph.2013.09.005

2. Kjems LL, Holst JJ, Volund A, Madsbad S. The influence of GLP-1 on glucose-stimulated insulin secretion: effects on beta-cell sensitivity in type 2 and nondiabetic subjects. Diabetes (2003) 52:380-6. doi:10.2337/diabetes.52.2.380

3. Xu G, Stoffers DA, Habener JF, Bonner-Weir S. Exendin-4 stimulates both beta-cell replication and neogenesis, resulting in increased beta-cell mass and improved glucose tolerance in diabetic rats. Diabetes (1999) 48:2270-6. doi:10.2337/diabetes.48.12.2270

4. Hellstrom PM, Naslund E, Edholm T, Schmidt PT, Kristensen J, Theodorsson E, et al. GLP-1 suppresses gastrointestinal motility and inhibits the migrating motor complex in healthy subjects and patients with irritable bowel syndrome. Neurogastroenterol Motil (2008) 20:649-59. doi:10.1111/j.13652982.2007.01079.x

5. Wettergren A, Schjoldager B, Mortensen PE, Myhre J, Christiansen J, Holst JJ. Truncated GLP-1 (proglucagon 78-107-amide) inhibits gastric and pancreatic functions in man. Dig Dis Sci (1993) 38:665-73. doi:10.1007/BF01316798

6. Gutzwiller JP, Goke B, Drewe J, Hildebrand P, Ketterer S, Handschin D, et al Glucagon-like peptide-1: a potent regulator of food intake in humans. Gut (1999) 44:81-6. doi:10.1136/gut.44.1.81

7. Holst JJ. The physiology of glucagon-like peptide 1. Physiol Rev (2007) 87:1409-39. doi:10.1152/physrev.00034.2006

8. Lu M, Wheeler MB, Leng XH, Boyd AE III. The role of the free cytosolic calcium level in beta-cell signal transduction by gastric inhibitory polypeptide and glucagon-like peptide I(7-37). Endocrinology (1993) 132:94-100. doi:10.1210/endo.132.1.8380389

9. Siegel EG, Creutzfeldt W. Stimulation of insulin release in isolated rat islets by GIP in physiological concentrations and its relation to islet cyclic AMP content. Diabetologia (1985) 28:857-61. doi:10.1007/BF00291078

10. Bocker D, Verspohl EJ. Role of protein kinase C, PI3-kinase and tyrosine kinase in activation of MAP kinase by glucose and agonists of G-protein coupled receptors in INS-1 cells. Int J Exp Diabetes Res (2001) 2:233-44. doi:10.1155/EDR.2001.233

11. Trumper A, Trumper K, Trusheim H, Arnold R, Goke B, Horsch D. Glucosedependent insulinotropic polypeptide is a growth factor for beta (INS-1) cells by pleiotropic signaling. Mol Endocrinol (2001) 15:1559-70. doi:10.1210/ me.15.9.1559 
12. Kojima M, Hosoda H, Date Y, Nakazato M, Matsuo H, Kangawa K. Ghrelin is a growth-hormone-releasing acylated peptide from stomach. Nature (1999) 402:656-60. doi:10.1038/45230

13. Wierup N, Bjorkqvist M, Westrom B, Pierzynowski S, Sundler F, Sjolund K. Ghrelin and motilin are cosecreted from a prominent endocrine cell population in the small intestine. J Clin Endocrinol Metab (2007) 92:3573-81. doi:10.1210/jc.2006-2756

14. Wierup N, Svensson H, Mulder H, Sundler F. The ghrelin cell: a novel developmentally regulated islet cell in the human pancreas. Regul Pept (2002) 107:63-9. doi:10.1016/S0167-0115(02)00067-8

15. Ariyasu H, Takaya K, Tagami T, Ogawa Y, Hosoda K, Akamizu T, et al. Stomach is a major source of circulating ghrelin, and feeding state determines plasma ghrelin-like immunoreactivity levels in humans. J Clin Endocrinol Metab (2001) 86:4753-8. doi:10.1210/jcem.86.10.7885

16. Tschop M, Smiley DL, Heiman ML. Ghrelin induces adiposity in rodents. Nature (2000) 407:908-13. doi:10.1038/35038090

17. Wren AM, Seal LJ, Cohen MA, Brynes AE, Frost GS, Murphy KG, et al. Ghrelin enhances appetite and increases food intake in humans. J Clin Endocrinol Metab (2001) 86:5992. doi:10.1210/jcem.86.12.8111

18. Wren AM, Small CJ, Abbott CR, Dhillo WS, Seal LJ, Cohen MA, et al. Ghrelin causes hyperphagia and obesity in rats. Diabetes (2001) 50:2540-7. doi:10.2337/diabetes.50.11.2540

19. Tong J, Prigeon RL, Davis HW, Bidlingmaier M, Kahn SE, Cummings DE, et al. Ghrelin suppresses glucose-stimulated insulin secretion and deteriorates glucose tolerance in healthy humans. Diabetes (2010) 59:2145-51. doi:10.2337/db10-0504

20. Kurashina T, Dezaki K, Yoshida M, Sukma Rita R, Ito K, Taguchi M, et al. The beta-cell GHSR and downstream cAMP/TRPM2 signaling account for insulinostatic and glycemic effects of ghrelin. Sci Rep (2015) 5:14041. doi:10.1038/ srep14041

21. Reimer MK, Pacini G, Ahren B. Dose-dependent inhibition by ghrelin of insulin secretion in the mouse. Endocrinology (2003) 144:916-21. doi:10.1210/ en.2002-220819

22. Colombo M, Gregersen S, Xiao J, Hermansen K. Effects of ghrelin and other neuropeptides (CART, MCH, orexin A and B, and GLP-1) on the release of insulin from isolated rat islets. Pancreas (2003) 27:161-6. doi:10.1097/00006676-200308000-00009

23. Wierup N, Yang S, McEvilly RJ, Mulder H, Sundler F. Ghrelin is expressed in a novel endocrine cell type in developing rat islets and inhibits insulin secretion from INS-1 (832/13) cells. J Histochem Cytochem (2004) 52:301-10. doi:10.1177/002215540405200301

24. Tschop M, Weyer C, Tataranni PA, Devanarayan V, Ravussin E, Heiman ML. Circulating ghrelin levels are decreased in human obesity. Diabetes (2001) 50:707-9. doi:10.2337/diabetes.50.4.707

25. le Roux CW, Patterson M, Vincent RP, Hunt C, Ghatei MA, Bloom SR. Postprandial plasma ghrelin is suppressed proportional to meal calorie content in normal-weight but not obese subjects. J Clin Endocrinol Metab (2005) 90:1068-71. doi:10.1210/jc.2004-1216

26. Shiiya T, Nakazato M, Mizuta M, Date Y, Mondal MS, Tanaka M, et al. Plasma ghrelin levels in lean and obese humans and the effect of glucose on ghrelin secretion. J Clin Endocrinol Metab (2002) 87:240-4. doi:10.1210/ jcem.87.1.8129
27. Perez-Tilve D, Gonzalez-Matias L, Alvarez-Crespo M, Leiras R, Tovar S, Dieguez C, et al. Exendin-4 potently decreases ghrelin levels in fasting rats. Diabetes (2007) 56:143-51. doi:10.2337/db05-0996

28. Banasch M, Bulut K, Hagemann D, Schrader H, Holst JJ, Schmidt WE, et al. Glucagon-like peptide 2 inhibits ghrelin secretion in humans. Regul Pept (2006) 137:173-8. doi:10.1016/j.regpep.2006.07.009

29. Chelikani PK, Haver AC, Reidelberger RD. Ghrelin attenuates the inhibitory effects of glucagon-like peptide-1 and peptide YY(3-36) on food intake and gastric emptying in rats. Diabetes (2006) 55:3038-46. doi:10.2337/ db06-0730

30. Gagnon J, Baggio LL, Drucker DJ, Brubaker PL. Ghrelin is a novel regulator of glucagon-like peptide-1 secretion. Diabetes (2015) 64:1513-21. doi:10.2337/ db14-1176

31. Xu G, Hong X, Tang H, Jiang S, Liu F, Shen Z, et al. Ghrelin regulates GLP-1 production through mTOR signaling in L cells. Mol Cell Endocrinol (2015) 416:9-18. doi:10.1016/j.mce.2015.08.016

32. Andersson U, Rosen L, Ostman E, Strom K, Wierup N, Bjorck I, et al. Metabolic effects of whole grain wheat and whole grain rye in the C57BL/6J mouse. Nutrition (2010) 26:230-9. doi:10.1016/j.nut.2009.06.007

33. Andersson U, Rosen L, Wierup N, Ostman E, Bjorck I, Holm C. A low glycaemic diet improves oral glucose tolerance but has no effect on betacell function in C57BL/6J mice. Diabetes Obes Metab (2010) 12:976-82. doi:10.1111/j.1463-1326.2010.01288.x

34. Tong J, Davis HW, Gastaldelli A, D’Alessio D. Ghrelin impairs prandial glucose tolerance and insulin secretion in healthy humans despite increasing GLP-1. J Clin Endocrinol Metab (2016) 101:2405-14. doi:10.1210/jc.2015-4154

35. Egido EM, Rodriguez-Gallardo J, Silvestre RA, Marco J. Inhibitory effect of ghrelin on insulin and pancreatic somatostatin secretion. Eur J Endocrinol (2002) 146:241-4. doi:10.1530/eje.0.1460241

36. Broglio F, Arvat E, Benso A, Gottero C, Muccioli G, Papotti M, et al. Ghrelin, a natural GH secretagogue produced by the stomach, induces hyperglycemia and reduces insulin secretion in humans. J Clin Endocrinol Metab (2001) 86:5083-6. doi:10.1210/jcem.86.10.8098

37. Fusco A, Bianchi A, Mancini A, Milardi D, Giampietro A, Cimino V, et al. Effects of ghrelin administration on endocrine and metabolic parameters in obese women with polycystic ovary syndrome. J Endocrinol Invest (2007) 30:948-56. doi:10.1007/BF03349243

38. Dornonville de la Cour C, Lindqvist A, Egecioglu E, Tung YC, Surve V, Ohlsson C, et al. Ghrelin treatment reverses the reduction in weight gain and body fat in gastrectomised mice. Gut (2005) 54:907-13. doi:10.1136/gut.2004. 058578

Conflict of Interest Statement: The authors declare that the research was conducted in the absence of any commercial or financial relationships that could be construed as a potential conflict of interest.

Copyright (c) 2017 Lindqvist, Shcherbina, Fischer and Wierup. This is an open-access article distributed under the terms of the Creative Commons Attribution License (CC $B Y)$. The use, distribution or reproduction in other forums is permitted, provided the original author(s) or licensor are credited and that the original publication in this journal is cited, in accordance with accepted academic practice. No use, distribution or reproduction is permitted which does not comply with these terms. 